\title{
A COMPARISON OF CHLORAMPHENICOL AND AMPICILLIN AS BACTERICIDAL AGENTS FOR HAEMOPHILUS INFLUENZAE TYPE B
}

\author{
D. C. TURK \\ Bacteriology Department and Regional Public Health Laboratory, Radcliffe Infirmary, \\ Oxford $O X 26 H E$
}

ChLOR AMPHenicol was reported in 1950 to be successful in the treatment of haemophilus meningitis (Prather and Smith, 1950), and during the next decade it became the accepted antibiotic for this purpose (Haggerty and Ziai, 1960). Then, in 1963, ampicillin was shown to be a reasonable alternative (Ivler et al., 1964), and by 1971 it was possible to write: "Ampicillin is most often used to treat this disease because it has been shown to be as effective as chloramphenicol but lacks the toxic effects " (Schulkind, Altemeier and Ayoub, 1971), and: "Ampicillin sodium is currently the preferred drug for the treatment of meningitis due to Hemophilus influenzae type b" (Haltalin and Smith, 1971), though the latter statement was not so generally applicable in Britain as in North America. At about that time, however, reported failures of ampicillin to eradicate $H$. influenzae in cases of meningitis provoked a number of papers reviewing the choice between chloramphenicol and ampicillin (Haltalin and Smith, 1971; Barrett et al., 1972; Kandall, Davis and Abramowicz, 1972); and then, in 1974, came the first reports of meningitis due to strains of $H$. influenzae type $\mathrm{b}$ that were resistant to ampicillin by virtue of $\beta$-lactamase production (Tomeh $e$ t al., 1974; U.S. CENTER FOR DiSEASE CONTROL, 1974), with some deaths possibly due to the choice of ampicillin for treatment and a number of cases in which the infection was not controlled until ampicillin was replaced by chloramphenicol. An editorial in the Journal of the American Medical Association (Nelson, 1974) was entitled: "Should ampicillin be abandoned for treatment of Haemophilus influenzae disease?", and discussed the alternatives. The debate continues (Fallon, 1976).

Chloramphenicol is generally regarded as strictly a bacteristatic antibiotic; but in each edition of Antibiotic and Chemotherapy from the first (Barber and Garrod, 1963, p. 265) to the fourth (Garrod, Lambert and O'Grady, 1973, p. 354) the statement has been made, without supporting evidence, that it is bactericidal for $H$. influenzae in concentrations that can readily be achieved in cerebrospinal fluid. Conversely it is well known that ampicillin, at levels readily achieved in patients, is bactericidal to sensitive bacterial strains; but Lapinski and Flakas (1967) and May and his colleagues (Roberts et al., 1973; Want and May, 1975) demonstrated failure of high concentrations of ampicillin and of other penicillins to sterilise large inocula of $H$. influenzae, and the development of " $L$ forms" in such circumstances. It was a study of this induction of " $L$ forms " by ampicillin, and of the effects of comparably high chloramphenicol levels on large inocula of $H$. influenzae, which led to the work to be reported here. In outline, this consisted of adding heavy $\left(c .5 \times 10^{7}\right)$ or relatively light (c. $5 \times 10^{4}$ ) inocula of $H$. influenzae type b to $1-\mathrm{ml}$ amounts of broth containing chloramphenicol or ampicillin in concentrations ranging from 20 to $0.5 \mu \mathrm{g}$ per ml; and then subculturing these tubes after incubation for $6 \mathrm{~h}$ and $24 \mathrm{~h}$ at $37^{\circ} \mathrm{C}$ in such a way as to obtain an estimate of the number of surviving organisms. The action of amoxycillin was similarly tested against a few of the $H$. influenzae strains, although this antibiotic, because it is not yet available in a form suitable for parenteral administration, is not a valid alternative to the other two as a means of treating haemophilus meningitis.

Received 18 June 1976; accepted 26 July 1976.

J. MED. MICROBIOL.-VOL. 10 (1977) 


\section{MATERIALS AND METHODS}

Bacterial strains. All 27 of these were capsulate type-b H. influenzae, and all had been isolated from patients with meningitis. All were of normal chloramphenicol sensitivity, as judged by a disk-plate method; 25 were also ampicillin sensitive, but the other two were $\beta$-lactamase producers.

Culture media. Levinthal broth and chocolate agar were prepared essentially as described by Turk and May (1967), with Baltimore Biological Laboratories products.

Test procedures. Inocula consisted of $0 \cdot 2-\mathrm{ml}$ volumes of either an undiluted $18-\mathrm{h}$ Levinthal-broth culture of the strain to be tested or a 1 in 1000 dilution of that culture in Levinthal broth. Such inocula were added to tubes containing $0.8-\mathrm{ml}$ volumes of Levinthal broth plus chloramphenicol, ampicillin or amoxycillin in amounts that gave final concentrations of 20,10,5,2,1 and $0.5 \mu \mathrm{g}$ per ml, and to control tubes of Levinthal broth without antibiotics. The antibiotic-free control broth that had received the dilute inoculum was subcultured immediately, to give an estimate of the size of the inoculum; and all broth cultures were subcultured after incubation for $6 \mathrm{~h}$ and $24 \mathrm{~h}$ at $37^{\circ} \mathrm{C}$. Subculture was carried out by the use of a standard wire loop to transfer approximately $0.002 \mathrm{ml}$ of the broth to a chocolate-agar plate and to spread it over an area of about $10 \mathrm{~cm}^{2}$; the chocolate-agar plates were incubated overnight at $37^{\circ} \mathrm{C}$, and the colonies were counted.

\section{RESULTS}

For the sake of brevity, and for the lack of a more appropriate term, cultures from which no growth was obtained on subculture will be described here as "sterilised"; however, it is probable that use of larger samples or of different techniques for subculture would have revealed that some of them contained viable organisms.

\section{Exposure of ampicillin-sensitive strains to chloramphenicol or ampicillin}

The same 18-h broth culture of each of the 25 strains and the same 1 in 1000 dilution of it were used to inoculate sets of tubes containing broth dilutions of each of the two antibiotics and antibiotic-free broth control tubes. Colony counts from the unincubated antibioticfree controls inoculated with 1 in 1000 dilutions of $18-\mathrm{h}$ broth cultures ranged from 20 to 170 , indicating that these inocula contained about $1-8.5 \times 10^{4}$ and the undiluted inocula about $1-8 \cdot 5 \times 10^{7}$ living organisms.

Of the 50 antibiotic-free control cultures (one for each bacterial strain for each size of inoculum) all gave confluent growths on subculture after $6 \mathrm{~h}$ and after $24 \mathrm{~h}$, except that two of those with the smaller inocula gave heavy but non-confluent growths after $6 \mathrm{~h}$.

The results from the antibiotic-containing cultures in this group of experiments are summarised in the table. The following differences between the action of the two antibiotics are apparent.

(1) After $6 \mathrm{~h}$, chloramphenicol at a concentration of $20 \mu \mathrm{g}$ per $\mathrm{ml}$ had already sterilised 18 of the 25 heavily inoculated cultures, and even at $5 \mu \mathrm{g}$ per $\mathrm{ml}$ it had sterilised eight and allowed only one to produce a confluent growth on subculture. Ampicillin, on the other hand, at $20 \mu \mathrm{g}$ per $\mathrm{ml}$ had sterilised only two, and at $5 \mu \mathrm{g}$ per $\mathrm{ml}$ had allowed 19 to produce confluent growths.

(2) After $6 \mathrm{~h}$, chloramphenicol at 20 or $10 \mu \mathrm{g}$ per $\mathrm{ml}$ had sterilised all 25 lightly inoculated cultures, and even at $2 \mu \mathrm{g}$ per $\mathrm{ml}$ it had sterilised 23. Ampicillin produced much more variable results, with most strains giving light growths from some cultures and no growths from others, almost regardless of ampicillin concentrations; no concentration had sterilised more than 14 cultures, but even at $0.5 \mu \mathrm{g}$ per $\mathrm{ml}$ all strains were at least markedly inhibited by comparison with the antibiotic-free control cultures. The opening sentence of the Results section is of particular relevance to this set of findings.

(3) After $24 \mathrm{~h}$, chloramphenicol at $5 \mu \mathrm{g}$ per $\mathrm{ml}$ or more had sterilised all 25 heavily inoculated cultures and at $2 \mu \mathrm{g}$ per $\mathrm{ml}$ it had sterilised 20 , but $0.5 \mu \mathrm{g}$ per ml allowed confluent growths from all 25. Results with ampicillin were again variable, though with most 
TABLE

Colony counts given by 25 ampicillin-sensitive strains of Haemophilis influenzae type b after exposure to chloramphenicol or ampicillin

\begin{tabular}{|c|c|c|c|c|c|c|c|c|c|c|c|c|c|c|c|c|c|c|c|c|c|c|c|c|}
\hline \multirow{4}{*}{$\begin{array}{l}\text { Amount of } \\
\text { growth on } \\
\text { subcultures }\end{array}$} & \multicolumn{24}{|c|}{ Numbers of strains that gave growth as indicated in the left-hand column, when inoculated as } \\
\hline & \multicolumn{12}{|c|}{$\begin{array}{l}\text { undiluted 18-h culture into antibiotic concentrations } \\
\text { ( } \mu \mathrm{g} \text { per ml) of }\end{array}$} & \multicolumn{12}{|c|}{$\begin{array}{c}1 \text { in } 1000 \text { dilution of } 18-\mathrm{h} \text { culture into antibiotic } \\
\text { concentrations }(\mu \mathrm{g} \text { per } \mathrm{ml}) \text { of }\end{array}$} \\
\hline & \multicolumn{6}{|c|}{ chloramphenicol } & \multicolumn{6}{|c|}{ ampicillin } & \multicolumn{6}{|c|}{ chloramphenicol } & \multicolumn{6}{|c|}{ ampicillin } \\
\hline & 20 & 10 & 5 & 2 & 1 & 0.5 & 20 & 10 & 5 & 2 & 1 & 0.5 & 20 & 10 & 5 & 2 & 1 & 0.5 & 20 & 10 & 5 & 2 & 1 & 0.5 \\
\hline $\begin{array}{l}\text { ter } 6 h \\
\text { No growth } \\
1-10 \text { Colonies } \\
11-100 \text { Colonies } \\
>100 \text { Colonies* } \\
\text { Confluent }\end{array}$ & $\begin{array}{r}18 \\
2 \\
3 \\
1 \\
1\end{array}$ & $\begin{array}{l}3 \\
7 \\
3 \\
1 \\
1\end{array}$ & $\begin{array}{l}8 \\
6 \\
7 \\
3 \\
1\end{array}$ & $\begin{array}{l}2 \\
0 \\
7 \\
7 \\
9\end{array}$ & $\begin{array}{r}0 \\
0 \\
2 \\
5 \\
18\end{array}$ & $\begin{array}{r}0 \\
0 \\
0 \\
0 \\
25\end{array}$ & $\begin{array}{r}2 \\
2 \\
3 \\
11 \\
7\end{array}$ & $\begin{array}{r}0 \\
0 \\
1 \\
10 \\
14\end{array}$ & $\begin{array}{r}0 \\
0 \\
0 \\
6 \\
19\end{array}$ & $\begin{array}{r}0 \\
0 \\
0 \\
4 \\
21\end{array}$ & $\begin{array}{r}0 \\
0 \\
0 \\
0 \\
25\end{array}$ & $\begin{array}{r}0 \\
0 \\
0 \\
0 \\
25\end{array}$ & $\begin{array}{r}25 \\
0 \\
0 \\
0 \\
0\end{array}$ & $\begin{array}{r}25 \\
0 \\
0 \\
0 \\
0\end{array}$ & $\begin{array}{r}24 \\
1 \\
0 \\
0 \\
0\end{array}$ & $\begin{array}{r}23 \\
2 \\
0 \\
0 \\
0\end{array}$ & $\begin{array}{r}14 \\
5 \\
6 \\
0 \\
0\end{array}$ & $\begin{array}{r}1 \\
3 \\
19 \\
2 \\
0\end{array}$ & $\begin{array}{r}9 \\
16 \\
0 \\
0 \\
0\end{array}$ & $\begin{array}{r}14 \\
11 \\
0 \\
0 \\
0\end{array}$ & $\begin{array}{r}13 \\
12 \\
0 \\
0 \\
0\end{array}$ & $\begin{array}{r}8 \\
16 \\
1 \\
0 \\
0\end{array}$ & $\begin{array}{r}11 \\
13 \\
1 \\
0 \\
0\end{array}$ & $\begin{array}{r}6 \\
15 \\
4 \\
0 \\
0\end{array}$ \\
\hline $\begin{array}{l}\text { ter } 24 h \\
\text { No growth } \\
1-10 \text { Colonies } \\
11-100 \text { Colonies } \\
>100 \text { Colonies* } \\
\text { Confluent }\end{array}$ & $\begin{array}{r}25 \\
0 \\
0 \\
0 \\
0\end{array}$ & $\begin{array}{r}25 \\
0 \\
0 \\
0 \\
0\end{array}$ & $\begin{array}{r}25 \\
0 \\
0 \\
0 \\
0\end{array}$ & $\begin{array}{r}23 \\
5 \\
0 \\
0 \\
0\end{array}$ & $\begin{array}{r}13 \\
4 \\
1 \\
0 \\
7\end{array}$ & $\begin{array}{r}0 \\
0 \\
0 \\
0 \\
25\end{array}$ & $\begin{array}{r}21 \\
4 \\
0 \\
0 \\
0\end{array}$ & $\begin{array}{r}15 \\
8 \\
2 \\
0 \\
0\end{array}$ & $\begin{array}{r}9 \\
10 \\
6 \\
0 \\
0\end{array}$ & $\begin{array}{r}8 \\
4 \\
13 \\
0 \\
0\end{array}$ & $\begin{array}{r}4 \\
6 \\
14 \\
1 \\
0\end{array}$ & $\begin{array}{r}2 \\
6 \\
13 \\
4 \\
0\end{array}$ & $\begin{array}{r}25 \\
0 \\
0 \\
0 \\
0\end{array}$ & $\begin{array}{r}25 \\
0 \\
0 \\
0 \\
0\end{array}$ & $\begin{array}{r}25 \\
0 \\
0 \\
0 \\
0\end{array}$ & $\begin{array}{r}25 \\
0 \\
0 \\
0 \\
0\end{array}$ & $\begin{array}{r}25 \\
0 \\
0 \\
0 \\
0\end{array}$ & $\begin{array}{r}3 \\
2 \\
2 \\
3 \\
15\end{array}$ & $\begin{array}{r}25 \\
0 \\
0 \\
0 \\
0\end{array}$ & $\begin{array}{r}25 \\
0 \\
0 \\
0 \\
0\end{array}$ & $\begin{array}{r}25 \\
0 \\
0 \\
0 \\
0\end{array}$ & $\begin{array}{r}25 \\
0 \\
0 \\
0 \\
0\end{array}$ & $\begin{array}{r}25 \\
0 \\
0 \\
0 \\
0\end{array}$ & $\begin{array}{r}25 \\
0 \\
0 \\
0 \\
0\end{array}$ \\
\hline
\end{tabular}

* These were non-confluent growths, distinctly lighter than those given by the antibiotic-free control cultures.

strains the heaviness of growths was in general inversely related to ampicillin concentrations; no concentration had sterilised all of the cultures, but even at $0.5 \mu \mathrm{g}$ per ml no strain grew as heavily as in its control culture.

(4) After $24 \mathrm{~h}$, chloramphenicol at $1 \mu \mathrm{g}$ per $\mathrm{ml}$ had sterilised all 25 lightly inoculated cultures, but at $0.5 \mu \mathrm{g}$ per $\mathrm{ml}$ it allowed confluent growths from 15. Ampicillin at all concentrations sterilised all 25 cultures.

\section{Exposure of $\beta$-lactamase-producing strains to chloramphenicol or ampicillin}

The two $\beta$-lactamase-producing strains behaved in the same way as the previous 25 when exposed to chloramphenicol, but very differently when exposed to ampicillin. Both of them gave confluent growths on subculture at $6 \mathrm{~h}$ and $24 \mathrm{~h}$ from all heavily inoculated ampicillincontaining broths - even $20 \mu \mathrm{g}$ per $\mathrm{ml}$ had no apparent effect on their growths. On subculture from the lightly inoculated ampicillin-containing broths, one gave no growth on either occasion from the $20 \mu \mathrm{g}$ per $\mathrm{ml}$ and $10 \mu \mathrm{g}$ per ml cultures, a light growth after $6 \mathrm{~h}$ and a confluent growth after $24 \mathrm{~h}$ from the $5 \mu \mathrm{g}$ per $\mathrm{ml}$ culture, and confluent growths on both occasions from the remaining cultures; and the other gave a similar pattern of results shifted one tube down-it was the $2 \mu \mathrm{g}$ per ml culture that gave a light growth after $6 \mathrm{~h}$ and a confluent growth after $24 \mathrm{~h}$.

\section{Exposure of ampicillin-sensitive strains to amoxycillin}

Five of the original 25 strains were tested as before except that amoxycillin was substituted for chloramphenicol. Both ampicillin and amoxycillin gave results similar to those obtained with ampicillin on the previous occasion.

\section{Discussion}

Even the highest antibiotic concentrations used in these experiments were within ranges attainable in patients. The success of an antibiotic in treatment of meningitis probably depends to a large extent on the concentration that it can reach in the cerebrospinal fluid, but since the meninges have a blood supply, blood levels are also presumably relevant. 
Chloramphenicol levels of $20 \mu \mathrm{g}$ per $\mathrm{ml}$ and more are readily achieved in the blood of patients (Dupont et al., 1970), and cerebrospinal fluid levels of this antibiotic are commonly at least $30-50 \%$ of the blood levels (Garrod, Lambert and O'Grady, 1973, p. 138). Ampicillin levels well above $20 \mu \mathrm{g}$ per $\mathrm{ml}$ are also readily achieved in blood (Tuano et al., 1966), and cerebrospinal fluid levels as high as $38 \mu \mathrm{g}$ per $\mathrm{ml}$ in patients under treatment for meningitis were reported by Thrupp et al. (1966). However, in most cases they found much lower levels, and the ratio of cerebrospinal fluid level to blood level varied widely from patient to patient and from time to time, being highest (in some cases as high as 1:1) in the first few days of treatment when high cerebrospinal-fluid cell counts and protein levels indicated severe meningeal inflammation.

Choice of the most suitable antibiotic to use against a given pathogen is commonly based on comparisons of the inhibitory efficacy of the various candidates. Determinations of minimum inhibitory concentrations, by broth- or agar-dilution techniques, are usually regarded as the most reliable approach to the problem. These trends are reflected in nearly all of the very many papers (far too numerous to cite) that have been written in recent years about the antibiotic susceptibilities of $H$. influenzae; but many workers have reported difficulties in obtaining precise end-points in such tests when using ampicillin and other cellwall-active antibiotics. Bottone, Brandman and Schneierson (1976) recently suggested that this difficulty, attributable to the formation of spheroplasts (the " $L$ forms " of early workers referred to above) can be avoided by keeping the inocula small; they recommend $10^{4}$ organisms per $\mathrm{ml}$.

This recommendation, a good one if the object is to devise a test that is easily read and gives reproducible results, does not necessarily indicate the best way of obtaining information relevant to the clinical situation. The antibiotic that is the most effective inhibitor of a carefully restricted number of bacteria exposed to it for $18 \mathrm{~h}$ or more in a tube or on a plate may not be the one with the greatest potential influence on the course of a severe infection of the meninges or elsewhere. It may be that a bactericidal antibiotic is preferable to a bacteristatic one for treatment of meningitis; it may be that ability to deal effectively with large bacterial populations is also desirable, at least in some cases; and it may be that what happens within the first few hours of encounter between antibiotic and organism is important, especially if the antibiotic concentration at the relevant site is only intermittently at an effective level. If these postulates happen to be true, the superiority of chloramphenicol over ampicillin as a means of killing large numbers of $H$. influenzae type b quickly, demonstrated in the results reported here, may mean that it is the better agent of the two for treating haemophilus meningitis. Since ampicillin itself gives good results in most cases, there is no scope for chloramphenicol to do markedly better in large series, but it might be expected to produce a more rapid resolution of infection and to be rather more reliably effective, even against ampicillin-sensitive strains. There is clinical evidence that these expectations are in fact fulfilled; Shackelford et al. (1972) found that fever tended to be higher and more prolonged in patients with haemophilus meningitis treated with ampicillin than in those treated with chloramphenicol; and reference has already been made at the beginning of this paper to reports that ampicillin sometimes fails to achieve bacteriological cure despite normal sensitivity of the organism. Thus chloramphenicol seems to be the best antibiotic available for treatment of any case of haemophilus meningitis, not just the one to which we are driven back by the increasing risk that the causative organism can produce $\beta$-lactamase.

\section{SUMMARY}

In tests of bactericidal action against $H$. influenzae type b strains isolated from patients with meningitis, chloramphenicol was found to be far more reliable than ampicillin in dealing with large inocula, and more rapidly effective against both large and relatively small inocula. These findings provide a laboratory explanation for the somewhat better record of chloramphenicol as an agent for treatment of haemophilus meningitis.

I am grateful to Mr David Gardiner for technical assistance and to Dr G. Rolinson of Beecham Research Laboratories for a supply of amoxycillin. 


\section{REFERENCES}

Barber, M. AND Garrod, L. P. 1963. Antibiotic and chemotherapy, Edinburgh.

Barrett, F. F., Taber, L. H., Morris, C. R., Stephenson, W. B., Clark, D. J. and Yow, M. D. 1972. A 12 year review of the antibiotic management of Haemophilus influenzae meningitis. J. Pediat., 81, 370.

Bottone, E. J., Brandman, Z. AND Schneierson, S. S. 1976. Spheroplasts of Haemophilus influenzae induced by cell wall-active antibiotics and their effect upon the interpretation of susceptibility tests. Antimicrob. Agents Chemother., 9, 327.

Dupont, H. L. Hornick, R. B., Weiss, C. F., SNyder, M. J. and Woodward, T. E. 1970. Evaluation of chloramphenicol acid succinate therapy of induced typhoid fever and Rocky Mountain spotted fever. New Engl. J. Med., 282, 53.

FALLON, R. J. 1976. Haemophilus influenzae meningitis. J. antimicrob. Chemother., 2, 3.

Garrod, L. P., Lambert, H. P. and O'Grady, F. 1973. Antibiotic and chemotherapy, 4th. ed., Edinburgh.

HAGGerTy, R. J. AND ZIAI, M. 1960. Acute bacterial meningitis in children. A controlled study of antimicrobial therapy with particular reference to combinations of antibiotics. Pediatrics, 25, 742.

Haltalin, K. C. AND Smith, J. B. 1971. Re-evaluation of ampicillin for Haemophilus influenzae meningitis. An appraisal based on a review of cases of persistent or recurrent infection. Am. J. Dis. Child., 122, 328.

Ivler, D., Thrupp, L. D., Leedom, J. M., Wehrle, P. F. ANd Portnoy, B. 1964. Ampicillin in the treatment of acute bacterial meningitis. In Antimicrobial agents and chemotherapy-1963, edited by J. C. Sylvester, Ann Arbor, Mich., p. 335.

Kandall, S. R., Davis, T. C. AND AbramowiCz, M. 1972. Ampicillin failure in $H$. influenzae meningitis. A case report with added commentaries. Clin. Pediat., 11, 264.

LAPINSKI, E. M. AND FlaKAS, E. D. 1967. Induction of L forms of Haemophilus influenzae in culture and their demonstration in human bronchial secretions. J. Bact., 93, 1438.

Nelson, J. D. 1974. Should ampicillin be abandoned for treatment of Haemophilus influenzae disease? J. Am. med. Ass., 229, 322.

Prather, G. W. and Smith, M. H. D. 1950. Chloramphenicol in the treatment of Hemophilus influenzae meningitis. J. Am. med. Ass., 143, 1405.

RoberTs, D. E., INGOLD, A., WANT, S. V. AND MAY, J. R. 1974. Osmotically stable L forms of Haemophilus influenzae and their significance in testing sensitivity to penicillins. J. clin. Path., 27, 560.

Schulkind, M. L., Altemeier, W. A. ANd Ayoub, E. M. 1971. A comparison of ampicillin and chloramphenicol therapy in Hemophilus influenzae meningitis. Pediatrics, 48, 411.

Shackelford, P. G., Bobinski, J. E., Feigin, R. D. AND Cherry, J. D. 1972. Therapy of Haemophilus influenzae meningitis reconsidered. New Engl. J. Med., 287, 634.

Thrupp, L. D., Leedom, J. M., Ivler, D., Wehrle, P. F., Portnoy, B. ANd Mathies, A. W. 1966. Ampicillin levels in the cerebrospinal fluid during treatment of bacterial meningitis. In Antimicrobial agents and chemotherapy-1965, edited by G. L. Hobby, Ann Arbor, Mich., p. 206.

Tomeh, M. O., Starr, S. E., McGowan, J. E., Terry, P. M. and Nahmias, A. J. 1974. Ampicillin-resistant Haemophilus influenzae type b infection. J. Am. med. Ass., 229, 295.

Tuano, S. B., Johnson, L. D., Brodie, J. L. And Kirby, W. M. M. 1966. Comparative blood levels of hetacillin, ampicillin and penicillin G. New Engl.J. Med., 275, 635.

TURK, D. C. AND MAY, J. R. 1967. Haemophilus influenzae: its clinical importance, London, pp. 114-116.

U.S. Communicable Diseases Center. 1974. Morbidity and mortality weekly reports, Atlanta, Ga., vol. 23, pp. 77, 99, 205 and 259.

WANT, S. V. AND MAY, J. R. 1975. Induction of $L$ forms of Haemophilus influenzae in vitro. J. med. Microbiol., 8, 369. 